\title{
ĐÁNH GIÁ TÁC ĐộNG CỦA MộT SỐ YẾU TỐ TỬ NHIÊN VÀ NHÂN SINH ĐỂN NGẬP LỤT THÀNH PHỐ HỒ CHÍ MINH
}

\author{
Huỳnh Lưu Trùng Phùng ${ }^{1}$, Nguyễn Kỳ Phùng ${ }^{1}$, Lê Thị Hiền ${ }^{2}$
}

Tóm tắt: Thành phố Hồ Chí Minh (Tp. HCM) có hệ thống sông rạch dày đặc, rất thuận lợi cho giao thông thủy và cảnh quan sông nước, nhung lại có trở ngại lớn về ngập và tiêu thoát nước. Đây là một đô thị thường xuyên bị tác động của triều cường, mưa lớn vào mùa mưa, hệ thống thoát nước lạc hậu đang trong quá trình cải tạo khiến ngập lụt thường xảy ra trên diện rộng. Tình trạng này gây nhiều thiệt hại đến đời sống, của cải, sinh hoạt của nguời dân cũng nhu ảnh hưởng đến quá trình phát triển kinh tế - xã hội của thành phố. Để có cái nhìn tổng quan trong nhũng năm gần đây, Bài báo đã đánh giá chi tiết các yếu tố tư nhiên (mưa, triều, nước biển dâng) và các yếu tố nhân sinh (nhấn mạnh vào quá trình đô thị hóa) đến vấn đề ngập lụt của thành phố. Kết quả phân tích đã cho thấy được nguyên nhân chính là do mura vuợt tần suất xuất hiện ngày càng nhiều, triều ngày càng dâng cao dưới tác động của biến đổi khi hậu và tốc độ đô thị hóa của khu vực nghiên cứu quá nhanh cũng nhu việc quy hoạch hệ thống cống thoát nước chưa phù hơp với điều kiện hiện tại. Kết quả của nghiên cưu cũng đã góp phần làm cơ sở đề xuất một số giải pháp hố trợ giải quyết tình trạng ngập úng tai Tp. HCM.

Từ khóa: Ngập lụt, Triều cuờng, Biến đổi khi hậu, Đô thị hóa.

Ban Biên tập nhận bài: 12/06/2019 Ngày phản biện xong: 12/07/2019 Ngày đăng bài:25/08/2019

\section{Mở đầu}

Thành phố Hồ Chí Minh (Tp. HCM) nằm trong vùng chuyển tiếp giữa miền Đông Nam Bộ và Đồng bằng sông Cửu Long với địa hình thấp dần từ Bắc xuống Nam và từ Tây sang Đông. Hơn nữa, thành phố nằm trong vùng ảnh hưởng của triều trong thời kỳ gió mùa Tây Nam (từ tháng 5 tới tháng 11) và chịu ảnh hưởng lớn từ tác động của biến đổi khí hậu nhất là khi nước biển dâng cao. Với vị trí nằm ở vùng hạ lưu sông Sài Gòn - Đồng Nai, giáp biển Đông và với khoảng $60 \%$ diện tích có cao độ từ $1,5 \mathrm{~m}$ trở xuống nên thành phố thường xuyên phải đối diện với vấn đề ngập, đặc biệt mỗi khi triều cường dâng cao nếu không có giải pháp phòng chống hiệu quả. Ngoài ra, theo trung tâm chống ngập, cốt nền của khá nhiều vị trí của thành phố không đồng đều cùng với hệ thống thoát nước bị tắc nghẽn lâu đang tạo ra những rào cản khó khăn cho chương trình chống ngập trong nhiều năm qua. Mặc dù là một trong những trung tâm văn hóa, giáo dục quan trọng cũng như đóng vai trò là kinh tế mũi nhọn của cả nước, thế nhưng Tp. HCM lại phải đối đầu với vấn đề ngập lụt trong những năm gần đây, ảnh hưởng đến hình ảnh cũng như vẻ đẹp của thành phố.

Theo thống kê so sánh các điểm ngập nặng do triều cường của trung tâm chống ngập, vào năm 2008, thành phố có 95 điểm ngập nặng do triều và ó xu hướng giảm dần từ năm 2009 - 2011 lần lượt là 40, 26, 10 điểm. Thế nhưng đến năm 2013, mặc dù đã xử lý được 9 điểm ngập nhưng lại phát sinh thêm đến 21 điểm ngập mới [4].

Hơn nữa, trung tâm Quản lý nước và Biến Đổi Khí Hậu tại Trung tâm Điều hành chương trình chống ngập nước thành phố với chủ đề Quy

${ }^{1}$ Sỏ Khoa hoc và Công nghệ TP. HCM

${ }^{2}$ Viện Khoa hoc và Công nghệ Tính toán

Email:kyphungng@gmail.com 
hoạch tích hợp để kiểm soát ngập Tp. HCM đã có đề cập đến vấn đề diễn biến mực nước có xu hướng tăng liên tục. Mực nước tại trạm Phú An trước đây chỉ ở khoảng 1,2 - 1,3m nhưng đến năm 2012 đã lên đến $1,5 \mathrm{~m}$ và thậm chí chạm đến mức $1,6 \mathrm{~m}$ dẫn đến các công trình chống ngập sẽ bị lạc hậu.

Vấn đề này đã được người dân Thành phố, các nhà khoa học và chính quyền hết sức quan tâm, đầu tư, nghiên cứu nhằm tìm ra giải pháp giảm ngập cho Thành phố. Hiện nay, Thành phố đã và đang có rất nhiều công trình được chính quyền đầu tư xây dựng phục vụ công tác chống ngập, các công trình này đã phần nào phát huy được tác dụng nhưng vẫn chưa hoàn toàn khắc phục được vấn đề ngập của Thành phố. Khi triển khai xây dựng các công trình chống ngập theo quy hoạch được phê duyệt, thực tế phát sinh những vấn đề như sau: Thiếu kinh phí để thực hiện hoàn tất các công trình theo quy hoạch; Tốc độ đô thị hóa nhanh chóng và không kiểm soát được, dẫn đến kênh rạch của Thành phố bị san lấp; Ảnh hưởng của biến đổi khí hậu; Ý thức của người dân trong việc bảo vệ môi trường, xả rác thải không đúng quy định góp phần gây tắc nghẽn hệ thống thoát nước; ...

Để làm sáng tỏ những vấn đề trên, Bài báo đã dựa vào những số liệu quan trắc thực tế để đánh giá phân tích những nguyên nhân chính gây ra ngập, từ đó là cơ sở đề xuất một số giải pháp hỗ trợ chống ngập tại Tp. HCM.

\section{Khu vực nghiên cứu}

Nằm ở miền Nam Việt Nam, khu vực nghiên cứu cách Hà Nội $1.730 \mathrm{~km}$ theo đường bộ, trung tâm thành phố cách bờ biển Đông $50 \mathrm{~km}$ theo đường chim bay.

Với vị trí tâm điểm của khu vực Đông Nam Á, Tp. HCM là một đầu mối giao thông quan trọng về cả đường bộ, đường thủy và đường hàng không, nối liền các tỉnh trong vùng và còn là một cửa ngõ quốc tế.

Địa hình khu vực nghiên cứu có thể chia thành 3 tiểu vùng nhỏ như sau:

- Vùng cao nằm ở phía Bắc - Đông Bắc và một phần Tây Bắc (thuộc Bắc huyện Củ Chi, Đông Bắc quận Thủ Đức và quận 9), với dạng địa hình lượn sóng, độ cao trung bình $10-25 \mathrm{~m}$ và xen kẽ có những đồi gò độ cao tới $32 \mathrm{~m}$, như đồi Long Bình (Quận 9).

- Vùng thấp trũng ở phía Nam-Tây Nam và Đông Nam thành phố (thuộc các quận $9,8,7$ và các huyện Bình Chánh, Nhà Bè, Cần Giờ). Vùng này có độ cao trung bình trên dưới $1 \mathrm{~m}$ và cao nhất $2 \mathrm{~m}$, thấp nhất $0,5 \mathrm{~m}$.

- Vùng trung bình, phân bố ở khu vực Trung tâm Thành phố, gồm phần lớn nội thành cũ, một phần các quận 2 , Thủ Đức, toàn bộ quận 12 và huyện Hóc Môn. Vùng này có độ cao trung bình $5-10 \mathrm{~m}$.

Phạm vi nghiên cứu được trình bày như hình 1 .

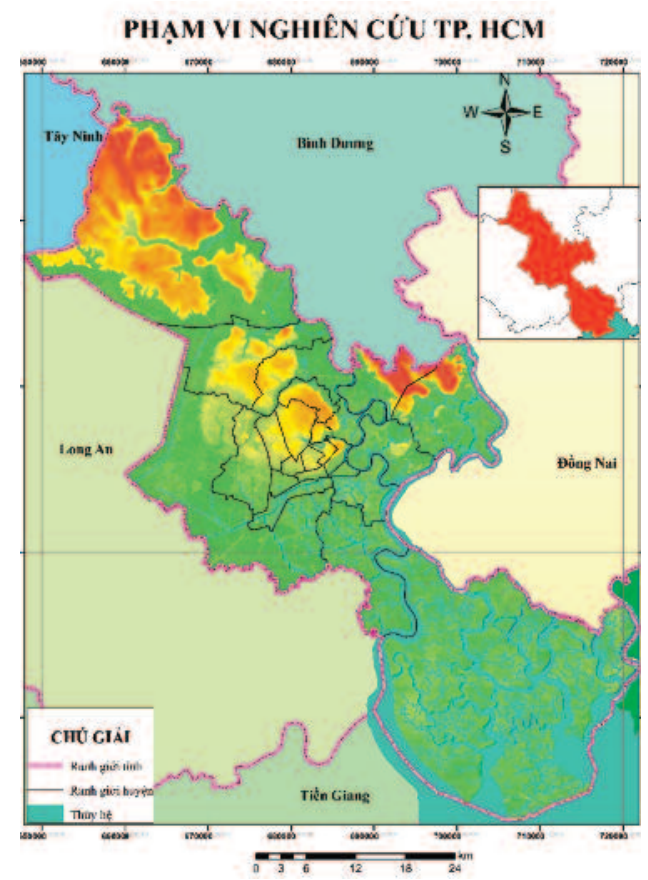

Hình 1. Khu vưc nghiên cúu

\section{Số liệu và phương pháp nghiên cứu}

\subsection{Số liệu}

Số liệu dùng để phân tích đánh giá bao gồm:

+ Số liệu mưa các trạm tại Tp. HCM (giai đoạn 1986 - 2014) để đánh giá tần suất xuất hiện các trận mưa lớn;

+ Mực nước (1980 - 2015) tại các trạm Phú An, Nhà Bè, Vũng Tàu phục vụ đánh giá xu thế biến đổi mực nước [3];

+ Bản đồ sử dụng đất của TP. HCM phục vụ 


\section{BÀI BÁO KHOA HỌC}

đánh giá quá trình đô thị hóa tại khu vực nghiên cứu [2].

\subsection{Phương pháp nghiên cứu}

Phương pháp thu thập và phân tích các số liệu, dữ liệu trong quá khứ là phương pháp chính trong bài báo. Nghiên cứu sử dụng phương pháp tổng hợp phân tích số liệu kết hợp với hệ thống thông tin địa lý (GIS) xây dựng, đánh giá các loại bản đồ phân loại đô thị - phi đô thị, bản đồ mặt nước và không phải mặt nước.

\section{Kết quả phân tích, đánh giá}

Tp. HCM được bao bọc bởi 3 hệ thống sông
Đồng Nai, Sài Gòn, Vàm Cỏ, có nhiều cửa xâm nhập nước vào Thành phố. Kết quả phân tích cho thấy các nguyên nhân chính ngập ở Tp. HCM là do mưa, triều, mực nước dâng, tổ hợp mưa kết hợp triều cường, lũ thượng nguồn và sự phát triển đô thị hóa.

\subsection{Do mura}

a. Xu thế biến đổi lượng mưa

Xu thế biến đổi lượng mưa năm trạm Cần Giờ, trạm Tân Sơn Hòa qua các giai đoạn được thể hiện như hình 2 và hình 3 .

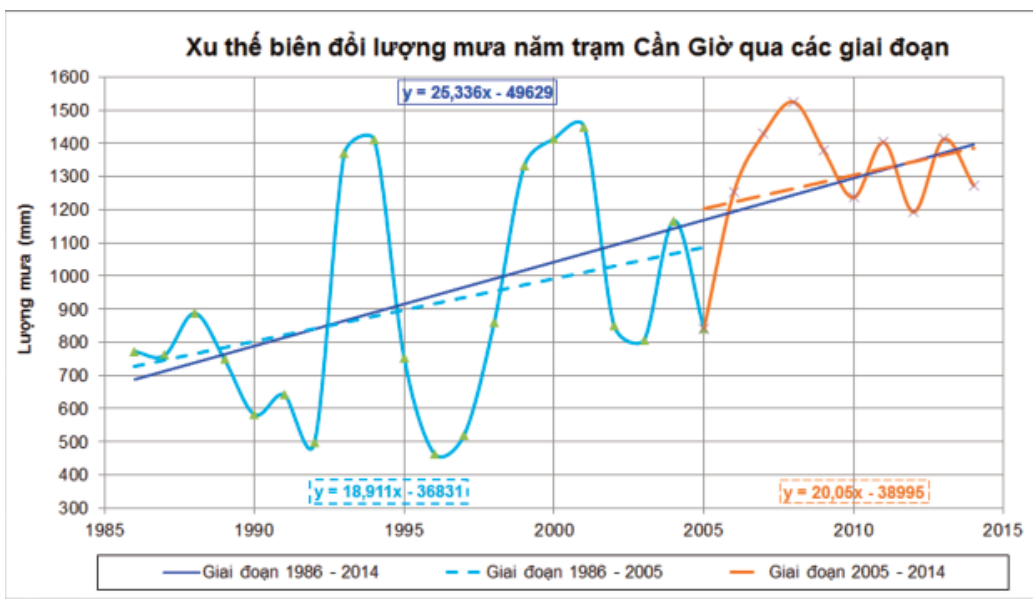

Hình 2. Xu thế biến đổi lượng mura năm trạm Cần Giờ qua các giai đoạn

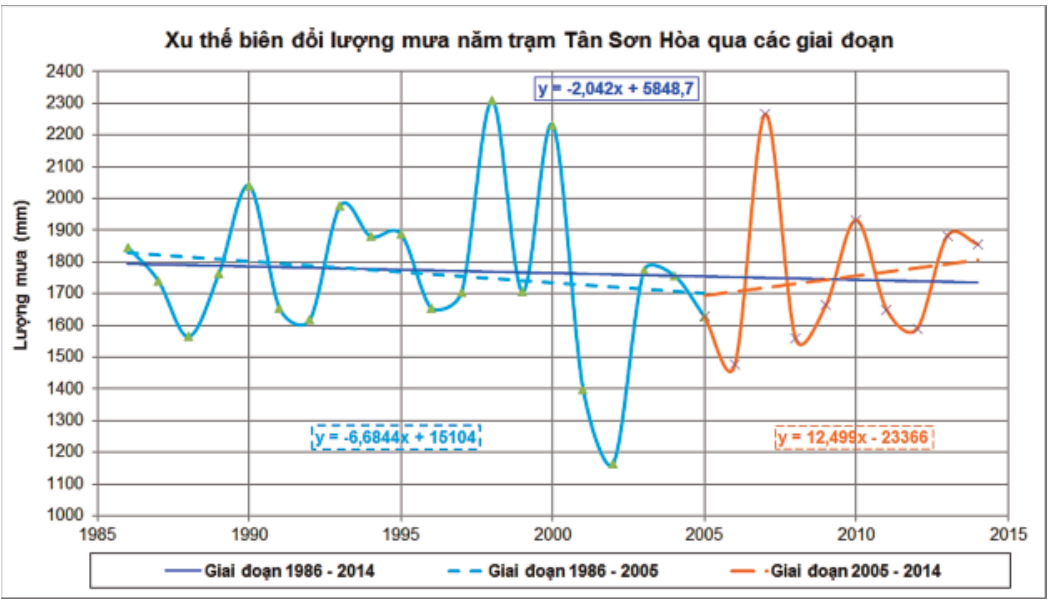

Hình 3. Xu thế biến đổi lương mura trạm Tân Sơn Hòa qua các giai đoạn

Kết quả phân tích, thống kê số liệu cho thấy:

- Giai đoạn 1986 - 2014: Lượng mưa trung bình có $x u$ hướng tăng tại trạm Cần Giờ $(25,3 \mathrm{~mm} / \mathrm{năm})$ và giảm tại trạm Tân Sơn Hòa (tốc độ giảm khoảng $2 \mathrm{~mm} /$ năm).

- Giai đoạn 1986 - 2005: Lượng mưa trung bình có xu hướng tương đồng với giai đoạn tổng, tăng ở trạm Cần Giờ và giảm ở trạm Tân Sơn Hòa. 
- Giai đoạn 2005 - 2014: Những năm gần đây, hầu như lượng mưa đều có xu hướng tăng, tốc độ tăng ở khoảng $20 \mathrm{~mm} /$ năm (trạm Cần Giờ) và $18.5 \mathrm{~mm} /$ năm (trạm Tân Sơn Hòa).

b. Mưa lớn vượt tần suất thiết kế

Theo Quy hoạch tổng thể thoát nước Tp. HCM đến năm 2020 Ban hành kèm theo Quyết định số 752/QĐ-TTg ngày 19 tháng 6 năm 2001 của Thủ tướng Chính phủ, tần suất thiết kế hệ thống thoát nước tương ứng với mưa có vũ lượng trong 3 giờ là 95,91mm (kênh, rạch); 85,36mm (cống cấp 2); 75,88mm (cống cấp 3), mực nước triều $+1,32 \mathrm{~m}$.

Theo số liệu thống kê trong vòng 40 năm: trên $100 \mathrm{~mm}$

- Năm 2002 - 2014: Xuất hiện 29 trận mưa trên 100mm. Trong đó riêng từ 2011 - 2014 đã có 12 trận mưa trên $100 \mathrm{~mm}$ làm quá tải hệ thống thoát nước [5].

\subsection{Do triều}

Chế độ triều của tuyến sông Sài Gòn thể hiện ở hình 5 cho thấy trạm Dầu Tiếng sau chân đập có mặt cắt sông nhỏ nên khá phụ thuộc vào dòng xả tràn của hồ Dầu Tiếng, tại trạm này có chân và đỉnh của mực nước lên khá cao $(\mathrm{H}=478 \mathrm{~cm}$ khi xả với lưu lượng là $600 \mathrm{~m}^{3} / \mathrm{s}$ vào năm 2000 ) ảnh hưởng trên sông Sài Gòn đến gần cửa Láng The (huyện Củ Chi).

- Năm 1962 - 2001: Xuất hiện 09 trận mưa

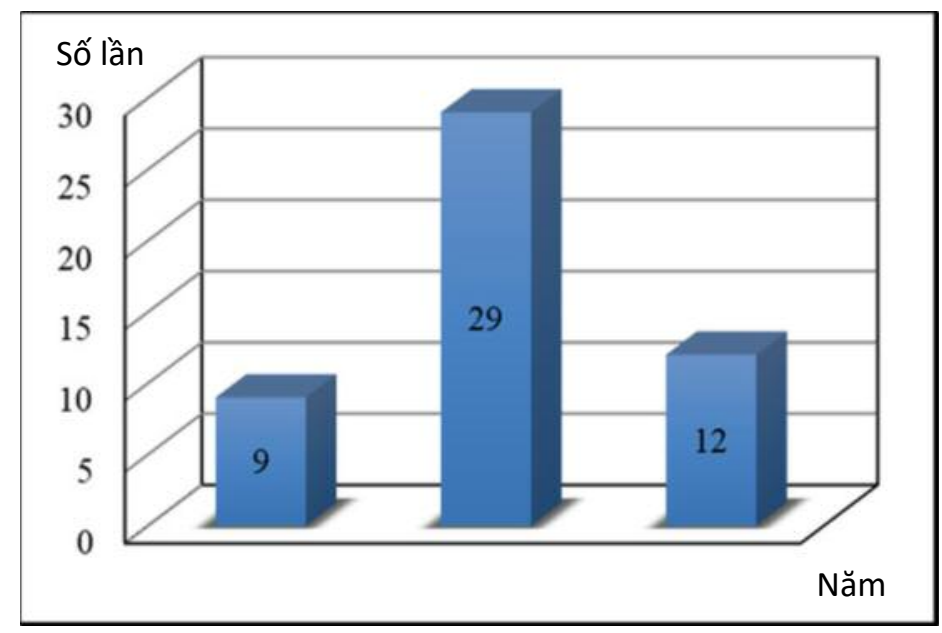

Hình 4. Tần suất xuất hiện mưa trên 100mm

Hình 6 thể hiện mực nước đỉnh triều, chân triều và đường xu thế tương ứng của 7 trạm cơ bản (Thời kỳ 1990 - 2011):

+ Mực nước đỉnh triều: ở các trạm đều có xu hướng tăng trong thời kỳ gần đây, đặc biệt tăng cao nhất là các trạm Bến Lức, Phú An, Thủ Dầu Một, Nhà Bè đều có hệ số đường xu thế cao hơn 1. Trong khi Trạm biển Vũng Tàu hệ số tăng chỉ 0.1829 .

+ Mực nước chân triều: Trên các trạm ở khu vực giữa của hạ du và ra đến Biển như Phú $A n$, Nhà Bè, Vũng Tàu mực nước thấp nhất có xu hướng rút xuống thấp hơn và hệ số đường xu thế âm $(<0)$ nhất là trạm Nhà Bè với hệ số góc đường xu thế là $\mathrm{a}=-1.6776)$ thể hiện rỏ sự rút sâu của mực nước thấp nhất hàng năm trong thời kỳ này.

Thành phố Hồ Chí Minh chịu ảnh hưởng trực tiếp của thủy triều xâm nhập từ Biển Đông thông qua hệ thống sông Sài Gòn - Đồng Nai và sông Vàm Cỏ Đông.

Trong 27 năm (từ 1980 đến 2007) liên tục đỉnh triều duy trì ở mức dưới báo động III $(+1,50$ m) tại trạm Phú An. Tuy nhiên, từ năm 2008 đến năm 2010 đỉnh triều ở mức cao trên báo động cấp III và chạm mức $+1,68 \mathrm{~m}$ (vượt báo động III $0,18 \mathrm{~m}$ ) vào năm 2013 và năm 2014. Số ngày triều có mực nước từ $1,50 \mathrm{~m}$ trở lên ngày càng xuất hiện nhiều hơn (trong 04 năm từ 2011 đến 2014 đã xuất hiện 76 lần, tăng 506,67\% so với 15 lần xuất hiện trong 04 năm từ 2006 đến 2010) (Hình 7). 


\section{BÀI BÁO KHOA HỌC}

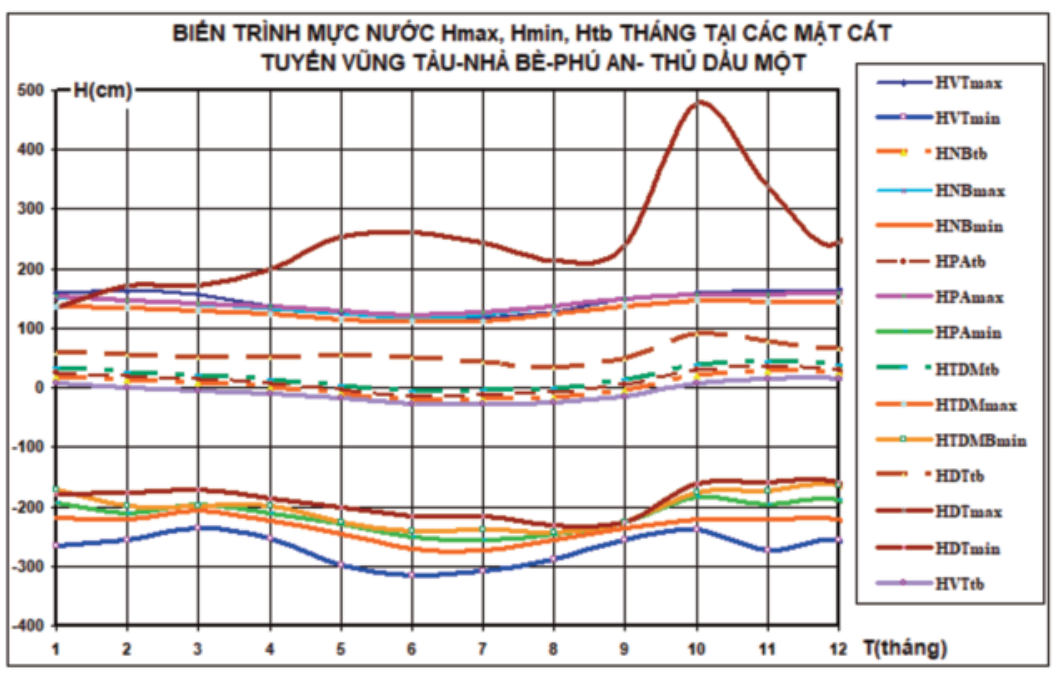

Hình 5. Biến trình mưc nước tháng tại các mặt cắt tuyến Vũng Tàu - Nhà Bè - Phú An - Thủ Dầu Một

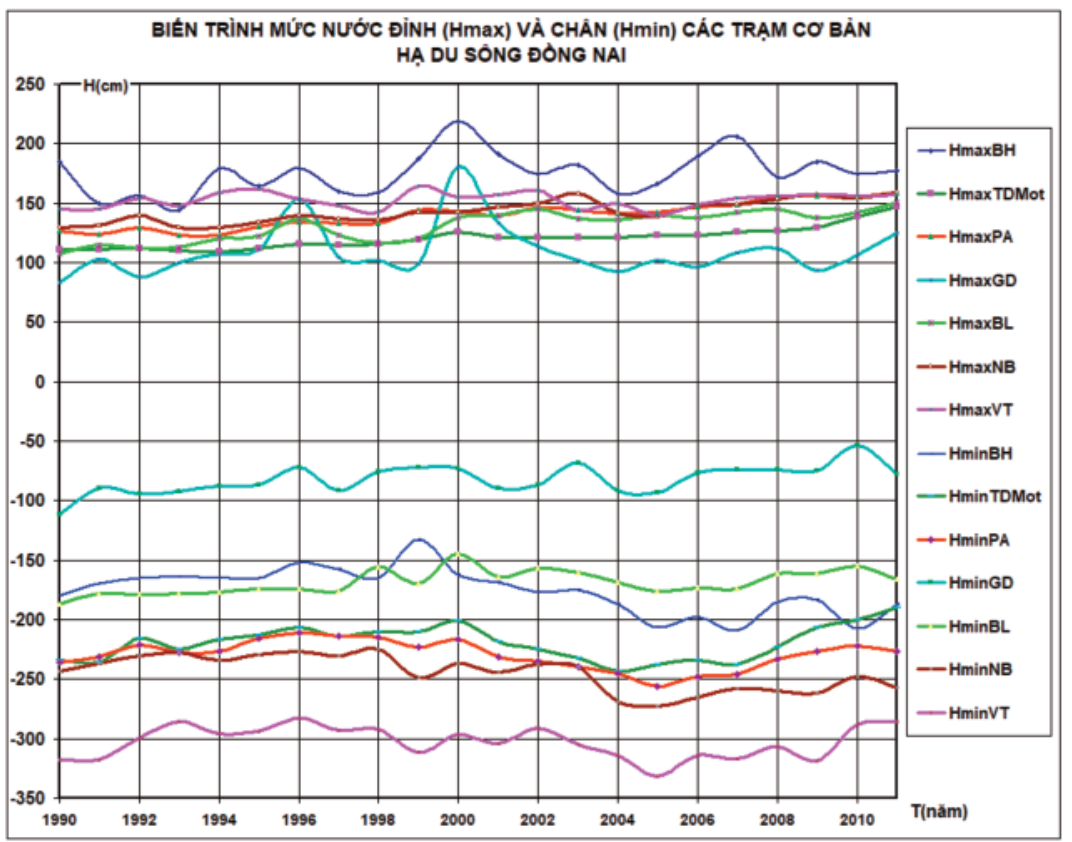

Hình 6. Biến trình mức nước đỉnh $\left(H_{\max }\right)$ và $\left(H_{\min }\right)$ các trạm cơ bản ha du sông Đồng Nai

\section{3. Ảnh hưởng mục nước dâng}

Theo số liệu mực nước thống kê trong 35 năm (từ năm 1980 - 2015) tại trạm Phú An cho thấy mực nước cực đại, trung bình và cực tiểu đều có xu thế tăng (Hình 8).
Hình 9 thể hiện rõ biến động của mực nước cực đại tại trạm Phú An, mực nước có xu thế tăng ở cả hai giai đoạn 1980 - 1999 và 2000 2015, tốc độ tăng mạnh (1.8mm/ năm) vào thời kỳ sau. 


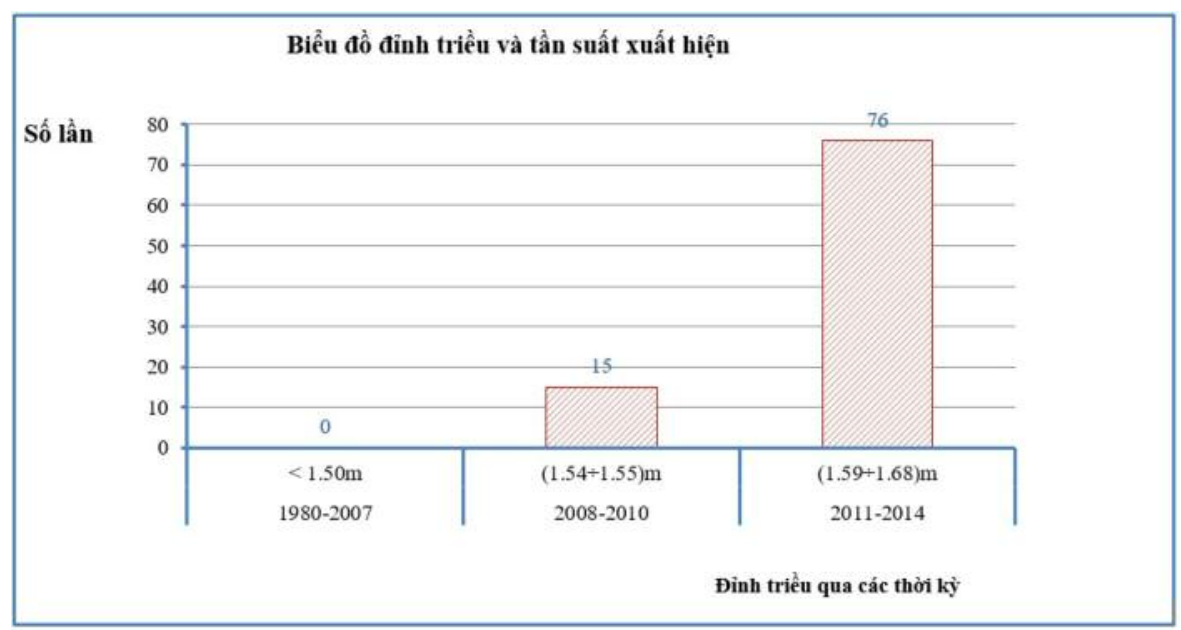

Hình 7. Biểu đồ đỉnh triều và tần suất xuất hiện

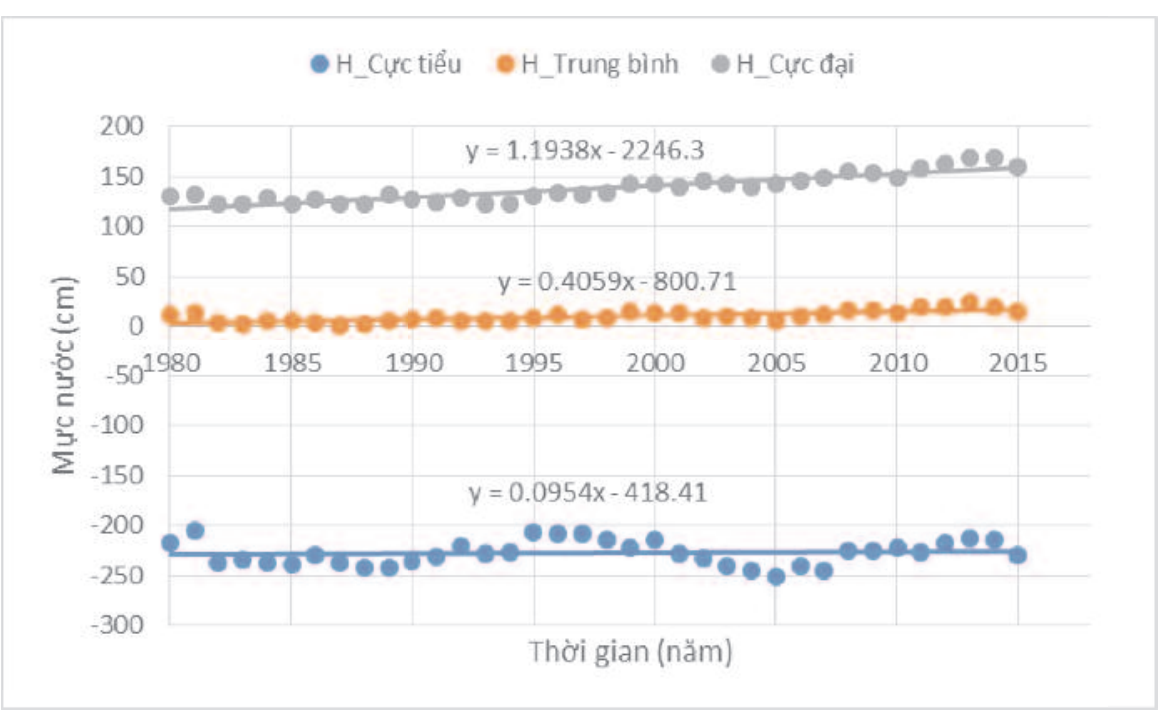

Hình 8. Xu thế biến đổi mực nước (cm) trạm Phú An giai đoạn 1980 - 2015

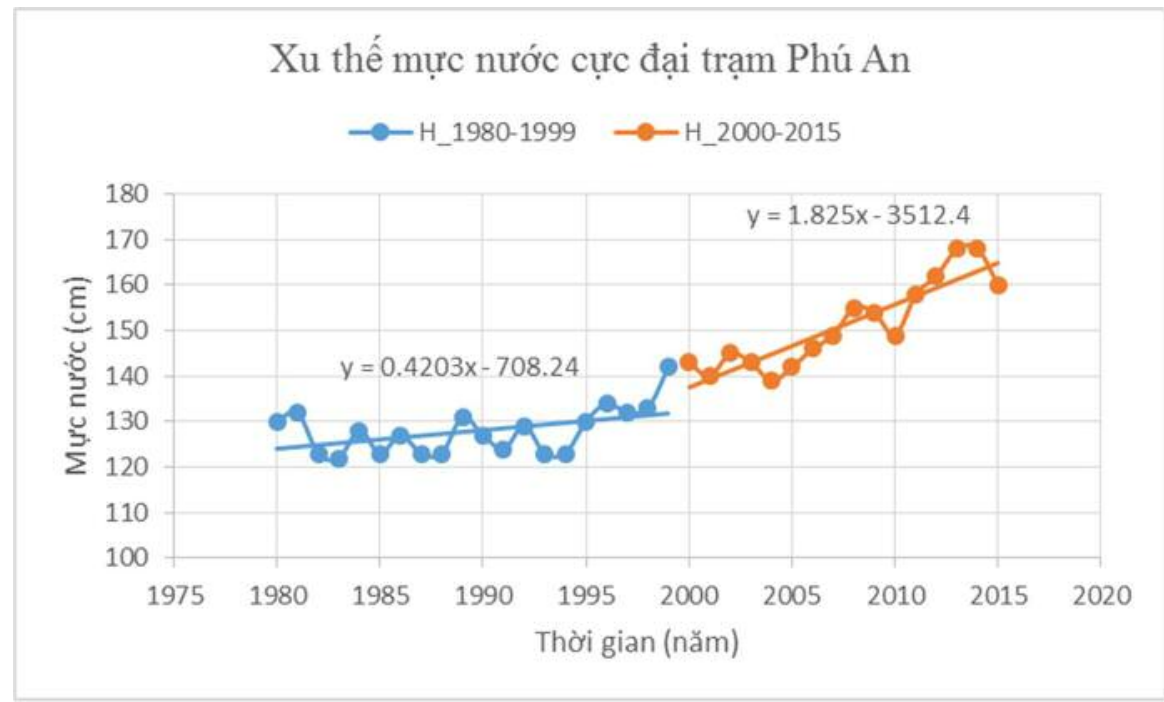

Hình 9. Xu thế biến đổi mục nước cực đại (cm) trạm Phú An giai đoạn 1980 - 2015 


\subsection{Tổ hợp mua kết hợp triều cường}

Trong thời gian từ năm 2007 trở về trước, rất ít xuất hiện tổ hợp bất lợi mưa lớn xuất hiện cùng lúc triều lên cao, nhưng trong 04 năm gần đây (2011 - 2014), tổ hợp bất lợi mưa kết hợp triều cường xuất hiện nhiều hơn và mưa diễn ra trên diện rộng so với cùng kỳ các năm trước (từ năm 2008 đến 2010 chỉ xuất hiện 03 lần tổ hợp bất lợi, nhưng từ năm 2011 đến 2014 xuất hiện 17 lần, tăng 466,67\%).

\subsection{Lũ thự̛ng nguồn}

Thành phố Hồ Chí Minh nằm hạ du sông Sài Gòn và Đồng Nai nên chịu ảnh hưởng xả lũ trực tiếp của Hồ Dầu Tiếng (thượng nguồn sông Sài Gòn) và Hồ Trị An (thượng nguồn sông Đồng Nai). Ngoài ra, thành phố còn chịu tác động của lũ từ hệ thống sông Mê Kông thông qua sông Vàm Cỏ Đông. Năm 2000, hồ Dầu Tiếng xả lũ với lưu lượng $600 \mathrm{~m}^{3} / \mathrm{s}$ và năm 2008 xả lũ với lưu lượng $400 \mathrm{~m}^{3} / \mathrm{s}$ đã gây ngập những nơi có cao trình thấp thuộc địa bàn huyện $\mathrm{Củ}$ Chi, Bình Chánh, Hóc Môn và Quận 12.

\section{6. Đô thị hóa}

Hiện nay Tp. HCM có 13 quận nội thành, 6 quận mới và 5 huyện ngoại thành. Việc điều chỉnh các đơn vị hành chính và thành lập các quận qua từng thời kỳ là điều minh chứng cho tiến trình đô thị hóa diễn ra tốc độ cao ở Tp. HCM. Có thể nhìn thấy khá rõ việc hình thành khu đô thị cũng như khu đô thị hóa trước và sau thời gian năm 1997 qua bảng 2.

Bảng 1. Tốc độ biến đổi (cm/năm) mục nước trạm Phú An qua các giai đoạn

\begin{tabular}{ccc}
\hline Trạm & $\begin{array}{c}\text { Giai đoạn } \\
1980-1999\end{array}$ & Giai đoạn 2000 - 2015 \\
\hline Cực tiểu & 0,816 & 1,047 \\
Trung bình & 0,174 & 0,740 \\
Cực đại & 0,420 & 1,820 \\
\hline
\end{tabular}

Bảng 2. Phân khu đô thị và đô thị hóa ở Tp. HCM

\begin{tabular}{|c|c|c|c|}
\hline Phân khu & Khu vực & Không gian & Tên quận \\
\hline \multicolumn{4}{|c|}{ Truoóc 1997} \\
\hline 1 & Đô thị & 8 quận nội thành & $\begin{array}{c}\text { 1,3,4,5,6,10,11, Phú } \\
\text { Nhuận }\end{array}$ \\
\hline 2 & $\begin{array}{l}\text { Khu đô } \\
\text { thị hóa }\end{array}$ & 4 quận ven & $\begin{array}{l}\text { 8, Tân Bình, Gò Vấp } \\
\text { và Bình Thạnh }\end{array}$ \\
\hline \multicolumn{4}{|c|}{ Sau 1997} \\
\hline $1+2$ & Đô thị & $\begin{array}{l}12 \text { quận nội thành cũ } \\
\text { và } 1 \text { quận tách từ Tân } \\
\text { Bình cũ }\end{array}$ & $\begin{array}{c}\text { 1,3,4,5,6,8,10,11, Phú } \\
\text { Nhuận, Tân Bình, Gò } \\
\text { Vấp, Bình Thạnh, Tân } \\
\text { Phú }\end{array}$ \\
\hline 3 & $\begin{array}{l}\text { Khu đô } \\
\text { thị hóa }\end{array}$ & $\begin{array}{l}5 \text { quận mới và } 1 \text { quận } \\
\text { tách từ huyện Bình } \\
\text { Chánh }\end{array}$ & $\begin{array}{l}\text { Quận 2,7,9,12, Thủ } \\
\text { Đức, Bình Tân }\end{array}$ \\
\hline
\end{tabular}




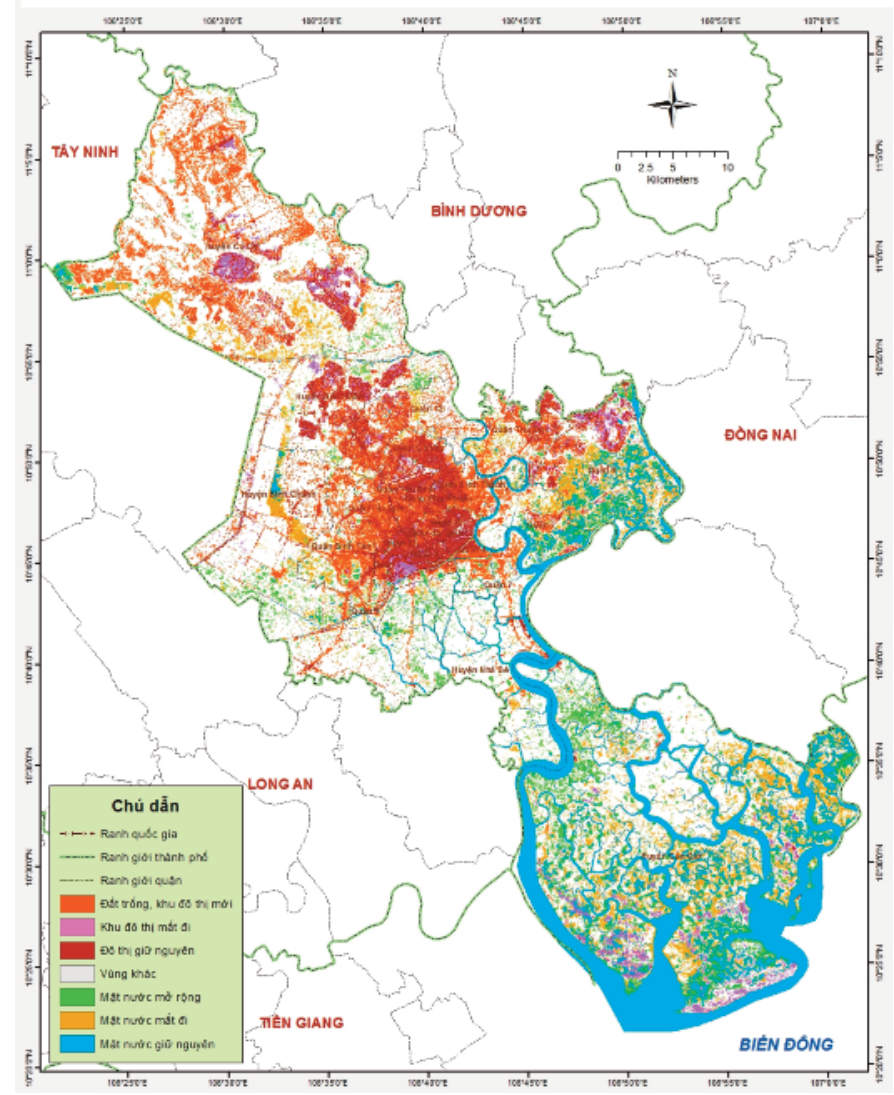

Hình 10. Phân bố không gian đô thị khu vục Tp.HCM năm 1988 - 2000

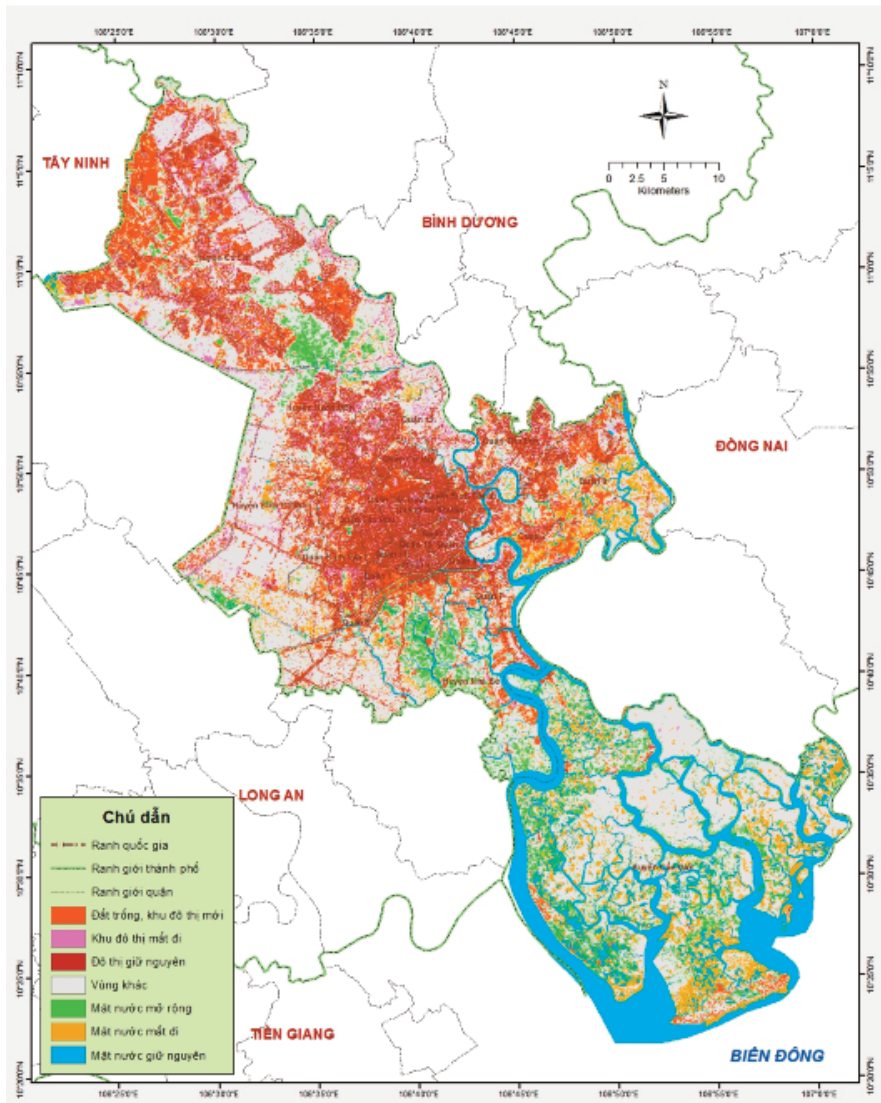

Hình 11. Phân bố không gian đô thị khu vục Tp.HCM năm 2000 - 2009 


\section{BÀI BÁO KHOA HỌC}

Các bản đồ phân bố không gian đô thị (Hình 10 - 11) cho thấy từ năm 1988 đến 2000, khu giữa TPHCM gồm 19 quận và 2 huyện phát triển mạnh theo hướng tập trung mở rộng ở khu vực phía Bắc thành phố, nơi đất cao và không bị ảnh hưởng bởi triều cường, đặc biệt là dọc theo các trục lộ chính ở khu vực ngoại thành. Tuy nhiên từ năm 2000 đến nay thành phố bắt đầu mở xuống phía Nam và phía Đông cùng với sự mở rộng trên các hướng.

Bảng 3 cho thấy diện tích đất đô thị tính đến năm 2014 chiếm tỉ lệ 43,3\% gần 1/2 diện tích nội đô cũ TPHCM và tăng gấp hơn 3 lần so với năm 1988.

Bảng 3. Diện tích đất đô thị thay đổi theo các năm qua phân tích ảnh viễn thám so với 1988

\begin{tabular}{ccc}
\hline Năm & Diện tích đô thị $\left(\mathrm{km}^{2}\right)$ & Tỷ lệ (\%) diện tích so với năm 1988 \\
\hline 1988 & 170,6526 & 100 \\
2000 & 351,4059 & 205,9 \\
2009 & 469,3284 & 275,1 \\
2014 & 561,6045 & 329,1 \\
\hline
\end{tabular}

Sự tăng trưởng diện tích đất đô thị các năm so với năm 1988 được thể hiện như Hình 12:

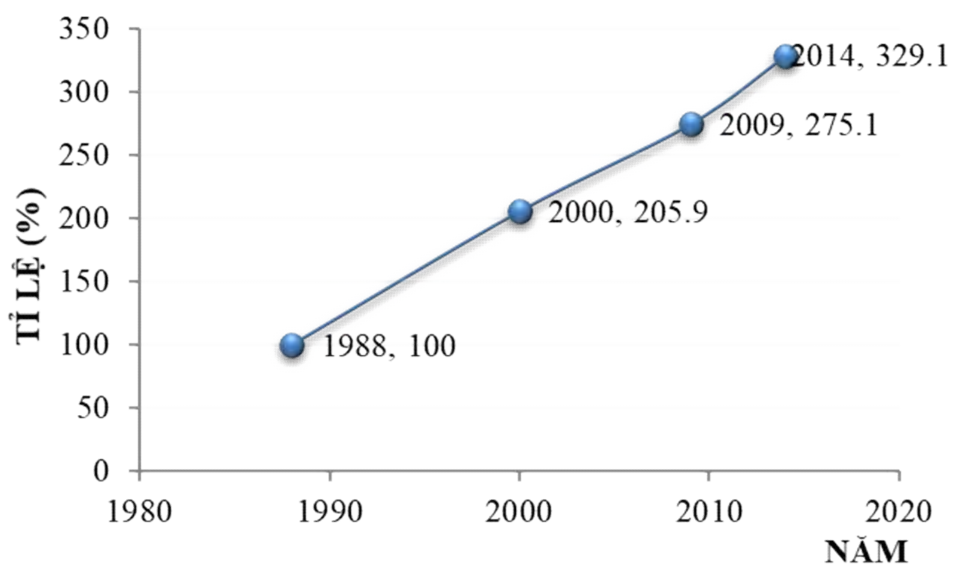

Hình 12. Biểu đồ tăng trưởng diện tích đô thị các năm so với 1988

Tăng trưởng diện tích không gian đô thị khác nhất, chứng tỏ giai đoạn này có sự bùng nổ đô thị nhau theo chu kỳ của ảnh vệ tinh quan sát. Trong hóa đáng kể về mặt tăng trưởng diện tích đất xây đó giai đoạn 2009-2014 có độ tăng trưởng cao dựng chỉ trong vòng 5 năm

Bảng 4. Diện tích đất đô thị TPHCM thay đổi qua các giai đoạn

\begin{tabular}{lccc}
\hline & \multicolumn{3}{c}{ Diện tích $\left(\mathrm{km}^{2}\right)$} \\
\cline { 2 - 4 } & $1988-2000$ & $2000-2009$ & $2009-2014$ \\
\hline Không đô thị & 1695,2274 & 1528,1496 & 1417,5306 \\
Đô thị mất đi & 61,3035 & 110,4588 & 127,6479 \\
Đô thị mở rộng & 242,0568 & 228,3813 & 220,0131 \\
Đô thị giữ nguyên & 109,3491 & 240,9471 & 341,4591 \\
\hline
\end{tabular}

Xét về phân bố không gian, kể từ năm 1988 đến 2014, đô thị phát triển từ các quận nội thành cũ, mở rộng dần ra các quận mới đến các huyện ngoại thành. Ở các khu vực ngoại thành đã và đang mọc lên các khu đô thị mới và xu hướng lấp đầy dần theo thời gian.

Tỷ lệ diện tích mặt nước Tp. HCM thay đổi qua các năm từ phân tích ảnh viễn thám được thể hiện qua Hình 13: 
Tỷ lệ (\%)

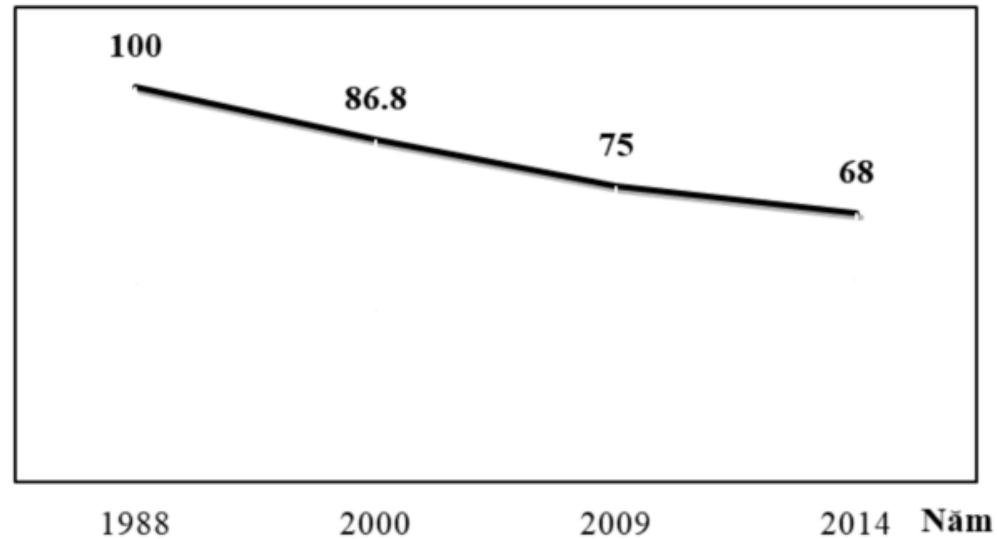

Hình 13. Biểu đồ suy giảm diện tích mặt nước vùng trũng, đầm lầy qua các năm

Biến động diện tích mặt nước theo thời gian qua các giai đoạn năm khác nhau như Hình 14, với diện tích phi mặt nước tăng dần theo các giai đoạn năm, diện tích mặt nước bị san lấp thay thế bằng đất trống hoặc đô thị.

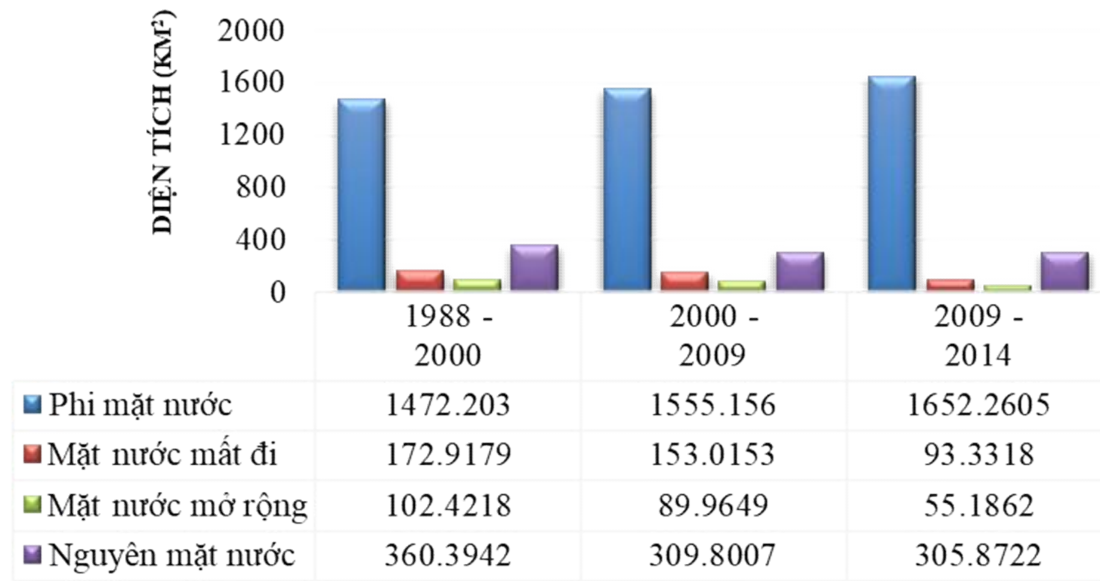

Hình 14. Biểu đồ biến động diện tích không gian mặt nước qua các năm

\section{Kết luận}

Kết quả nghiên cứu cho thấy:

+ Trong vòng 40 năm (1962 - 2014) xuất hiện 29 trận mưa trên $100 \mathrm{~mm}$. Trong đó riêng từ 2011 - 2014 đã có 12 trận mưa trên 100 mm làm quá tải hệ thống thoát nước.

+ Khi triều vượt đỉnh $1,5 \mathrm{~m}$, phần lớn diện tích $(2 / 3)$ Thành phố bị ảnh hường triều cường.

+ Hiện nay, dân số của Thành phố tăng đến 10 triệu người do đó hệ thống thoát nước không thể tải được lượng nước thải hơn gấp 4 lần so với thiết kế.

Theo phân tích chỉ ra rằng nguyên nhân chính gây ngập úng cho thành phố Hồ Chí Minh là do điều kiện bất lợi của tự nhiên (mưa, triều, ...) và các vấn đề trong công tác quản lý gây nên hệ thống thoát nước quá tải. Hiện nay, Thành phố chỉ tập trung vào 2 dự án chống ngập và chưa quan tâm đến những giải pháp khác có thể góp phần hạn chế tình trạng ngập úng. Do đó, bên cạnh việc tiếp tục xây dựng các công trình chống ngập theo quy hoạch đã được phê duyệt, Thành phố có thể xem xét một số giải pháp hỗ trợ trong điều kiện hiện nay như phục hồi hệ thống kênh rạch, phục hồi mảng xanh cho Thành phố và giảm dần diện tích bê tông hóa, xây dựng hồ điều tiết và tìm các giải pháp kỹ thuật giảm mực nước triều và giảm tác động xâm nhập mặn. 


\section{BÀI BÁO KHOA HỌC}

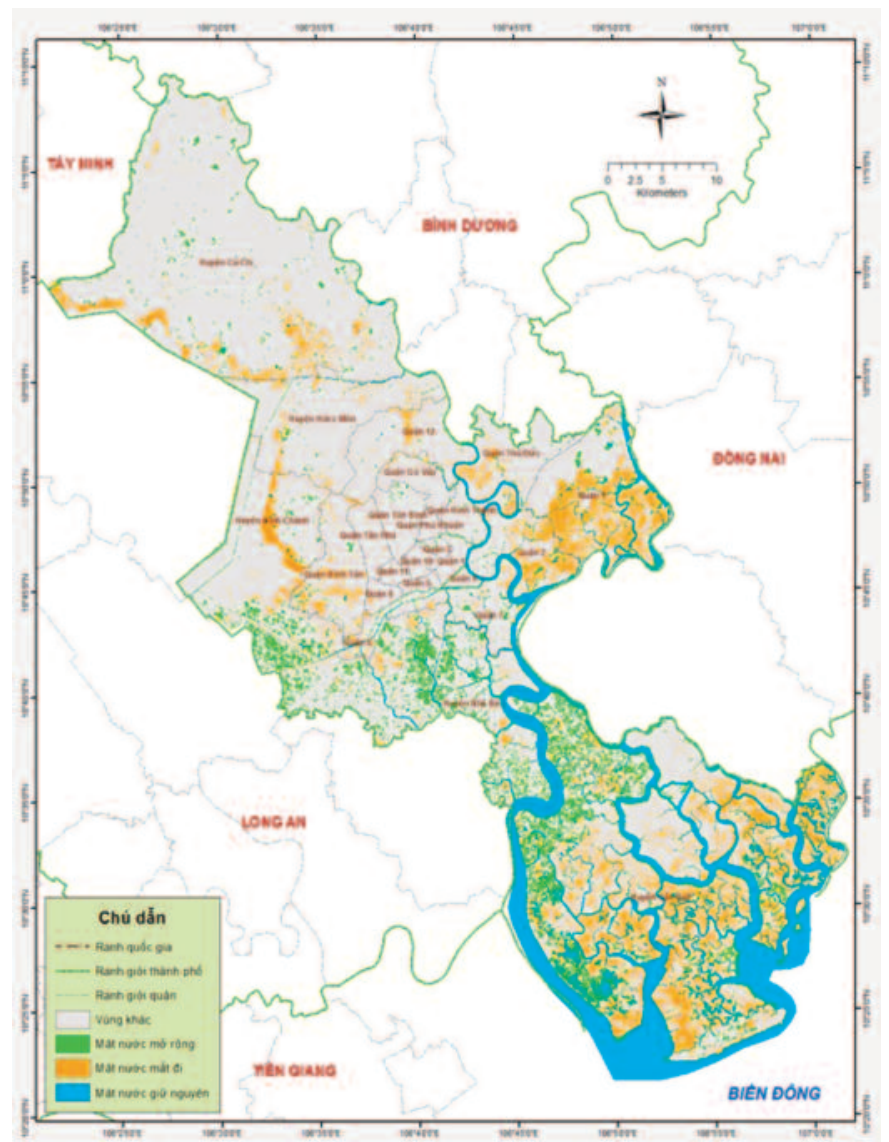

Hình 15. Phân bố thay đổi mặt nước Tp.HCM giai đoạn năm 1988 - 2014

\section{Tài liệu tham khảo}

1. Nguyễn Kỳ Phùng (2011), Tác động biến đổi khi hậu đến Tp. HCM và các giải pháp ứng phó. Nhà xuất bản Đại học quốc gia

2. Nguyễn Kỳ Phùng (2014), Atlas Khi tương thuỷ văn Tp. HCM, Nhà xuất bản Khoa học kỹ thuật.

3. Số liệu mực nước, mưa giai đoạn (1980-2015), Đài Khí tượng Thủy văn khu vực Nam Bộ.

4. Trung tâm điều hành chương trình chống ngập nước (2015), Cẩm nang tuyên truyền Phòng chống ngập bảo vệ công trình thoát nước trên địa bàn thành phố Hồ Chí Minh.

5. Ủy ban nhân dân Tp. HCM (2015), Đề án giải quyết ngập do triều cuờng khu vực Thành phố Hồ Chí Minh có xét đến biến đổi khí hậu. 


\title{
IMPACT ASSESSMENT OF SOME NATURAL FACTORS AND HUMAN TO URBAN FLOOD HO CHI MINH CITY
}

\author{
Huynh Luu Trung Phung1, Nguyen Ky Phung ${ }^{1}$, Le Thi Hien ${ }^{2}$ \\ ${ }^{1}$ Department of Science and Technology, HCMC \\ ${ }^{2}$ Institute for Computational Science and Technology
}

\begin{abstract}
Ho Chi Minh City has a dense network of canals, which is very favorable for water transportation and water landscape, but there are major obstacles to flooding and drainage. This is an urban often affected by spring tide, heavy rain during the rainy season, outdated drainage systems are undergoing renovations causing flooding usually occurs on a large scale. This situation has caused much damage to life, wealth and lives of people as well as affect the socio-economic development of the city. To get an overview in recent years, the article gave a detailed assessment of natural elements (rain, tides, sea level rise) and human factors (emphasis on the process of urbanization) to the city flooding problems. The analysis results have shown that the main reason is the increasingly appearance of excess rainfall and rising tide under the impact of climate change, rapid urbanization speeds as well as the city inappropriate sewer system planning to the present development conditions. The results of the study also contributed to the basis of proposing a number of solutions to support the flooding situation in Ho Chi Minh City.
\end{abstract}

Keywords: Flood, Spring tide, Climate change, Urbanization. 